\title{
KINERJA SATUAN POLISI PAMONG PRAJA DALAM PELAKSANAAN PERATURAN DAERAH NOMOR 9 TAHUN 2001 TENTANG LARANGAN MENGKONSUMSI MINUMAN KERAS DI KABUPATEN MAROS
}

\author{
Wahida Ardintiana Rasyid ${ }^{1}$, Lukman Hakim², Ansyari Mone ${ }^{3}$ \\ 1) Mahasiswa, Jurusan Ilmu Administasi Negara Unismuh Makassar \\ 2) Dosen, Jurusan Ilmu Administasi Negara Unismuh Makassar \\ 3) Dosen, Jurusan Ilmu Administasi Negara Unismuh Makassar
}

\begin{abstract}
This study aims to determine the performance of Pamong Praja Police Unit implementing the prevailing local regulations in Turikale District Maros Regency and factors influencing the performance of Pamong Praja Police Unit in implementation of Regional Regulation No. 9 of 2001 on the prohibition of consuming liquor in the Turikale District Maros Regency. This type of research was using qualitative type with informan counted 6 people. Data collection techniques using are observation, interview, and documentation. The results of this study indicate that the level of performance is still not maximal, because the understanding of Pamong Praja Police Unit to the organization is not good enough, the mindset complicates and slows down so that cause dissatisfaction is still felt bt the community as a result of lack of Pamong Praja Police Unit understanding in the field in the implementation of his dities.
\end{abstract}

Keywords: Performance, Pamong Praja Police Unit

\begin{abstract}
ABSTRAK
Penelitian ini bertujuan untuk mengetahui kinerja Satuan Polisi Pamong Praja yang melaksanakan peraturan daerah yang berlaku di Kecamatan Turikale Kabupaten Maros dan faktor-faktor yang mempengaruhi kinerja satuan polisi pamon praja dalam melaksanakan Peraturan Daerah Nomor 9 Tahun 2001 di Kabupaten Maros.Tipe penelitan yang digunakan adalah penelitian kualitatif dengan informan sebanyak 6 orang. Teknik pengumpulan data yang digunakan adalah observasi, wawancara dan dokumentasi. Hasil penelitian ini menunjukkan bahwa tingkat kinerja masih kurang maksimal, karena pemahaman pegawai Satuan Polisi Pamong Praja terhadap tugas pokok dan fungsi organisasi belum cukup baik, pola pikir yang mempersulit dan memperlambat sehingga menimbulkan ketidak puasan masih dirasakan oleh warga masyarkat sebagai akibat kurang paham aparat Satuan Polisi Pamong Praja di lapangan terhadap pelaksanaan tugasnya.
\end{abstract}

Kata kunci: Kinerja, Satuan Polisi Pamong Praja 


\section{PENDAHULUAN}

Bangsa Indonesia masih menghadapi berbagai masalah yang kurang mendukung, bahkan dapat menjadi hambatan serta rintangan untuk pembangunan nasional dimana pembangunan nasional tersebut memiliki dampak positif dan negatif. Sehubung dengan era globalisasi yang melanda dunia saat ini, banyak ditandai dengan berbagai perkembangan dan perubahan lingkungan. Dampak perubahan itu berpengaruh terhadap tatanan kehidupan manusia baik di bidang politik, ekonomi, hukum, pemerintah, dan kehidupan sosial budaya.

Dalam rangka mengantisipasi perkembangan dan dinamika kegiatan masyarakat seirama dengan tuntutan era globalisasi dan otonomi daerah, maka kondisi ketentraman dalam hidup bermasyarakat dan ketertiban umum daerah merupakan suatu kebutuhan dasar bagi seluruh lapisan masyarakat untuk meningkatkan mutu kehidupan. Sehubung dengan keinginan untuk mewujudkan ketentraman dan ketertiban umum daerah yang kondusif tersebut, disamping Lembaga atau Instansi Pemerintah Daerah membentuk Satuan Polisi Pamong Praja. (Pasal 148 ayat (1) Undang-Undang Nomor 32 Tahun 2004)

Tidak terciptanya kondisi yang di harapkan yakni ketenraman dan ketertiban yang baik di daerah, maka perlu dilakukan suatu pembinaan yang meliputi segala usaha, tindakan, pengarahan serta pengendalian segala sesuatu yang berkaitan dengan ketentraman dan ketertiban. Hal ini dipertegas dalam pasal 4 Peraturan Pemerintah Nomor 6 Tahun 2010 tentang Satuan Polisi Pamong Praja yang menyebutkan bahwa Satuan Polisi Pamong Praja mempunyai tugas menegakkan peratura daerah dan menyelenggarakan ketertiban umum dan ketentraman masyarakat serta perlindungan masyarakat.

Keamanan dan ketertiban masyarakat merupakan salah satu kebutuhan manusia. Masyarakat itu sesungguhnya manusia yang baik sebagai perorangan atau kelompokkelompokmanusiayangtelah 
berhimpun untuk memenuhi berbagai keperluan atau tujuan dalam hubungan bermasyarakat atau pergaulan sehingga perlu berinteraksi antara individu dan kelompok yang saling mebutuhkan satu sama lain.

Agar hubungan ini berjalan dengan baik dibutuhkan aturan atau kaidah-kaidah yang mengikat untuk melindungi, menghormati, dan hak orang lain serta memberikan rasa aman, dan tertib dalam kehidupan bermasyarakat.

Keberadaan Satuan Polisi Pamong Praja dalam pemerintah daerah mempunyai arti khusus yang cukup strategis karena Satuan Polisi Pamong Praja mempunyai tugaas membantu Kepala Daerah untuk menciptakan suatu kondisi daerah yang tentram, tertib, dan teratur, sehingga penyelenggaraan roda pemerintahan dapat berjalan sesuai dengan harapan dan masyarakat mampu melakukan rutinitasnya atau kegiatannya dengan aman tanpa tekanan. Untuk mewujudkan suatu

keadaan tersebut maka aparat pemerintahan perlu lebih intens dalam melakukan pengawasan kinerja para aparat yang bertugas menjalankan yang seharusnya dilakukan.

Sumber Daya Manusia (SDM) merupakan bagian terpenting dari pencapaian tujuan sebuah organisasi. Manusia sebagai sumber daya utama yang terampil sangat dibutuhkan dalam berbagai bidang karena sudah merupakan tuntutan dunia global. Dalam sebuah organisasi sumber daya manusia tersebut ditujukan untuk mencapai tujuan organisasi dan pengembangan individu yang bersangkutan dalam lingkup pekerjaan. Sumber daya manusia memiliki kedudukan sentral karena berperan dalam menentukan tingkat keefektifan dan keefisienan organisasi.

Salah satu masalah yang sangat memprihatikan dan harus mendapatkan perhatian serius dari pemerintah ialah masalah minuman keras yang banyak di komsumsi oleh masyarakat luas.

Minuman keras jika dikaitkan dari pandangan agama Islam, minuman Keras (atau disebut juga Khamar) mempunyai pengaruh kuat 
terhadap akal pikiranmanusia dan bisa mengakibatkan lupa diri. Allah swt. melarang umat Islam meminum Minuman Keras. Sebab, Minuman Keras itu adalah najis (diharamkan meminumnya) dan termasuk dalam satu perbuatan setan. Para ahli fiqh telah sepakat tentang pengharaman Minuman Keras. Dan siapa saja yang menolak pengharaman ini maka ia termasuk orang kafir yang keluar dari agama Islam.

Minuman Keras adalah minuman yang mengandung ETHANOL, yakni sejenis senyawa kimia organik yang memiliki gugus hidroksil $(-\mathrm{OH})$ yang utamanya terikat pada atom-2 Carbon (C) dan Hidrogen $(\mathrm{H})$, yang secara umum mampu Menurunkan Kesadaran.

Mengingat bahwa minuman keras dilarang di dalam agama Islam, bahkan termasuk salah satu dosa-dosa besar - baik bagi peminumnya maupun penjualnya.

Sehubung dengan adanya pelangaran terhadap Peraturan Daerah Nomor 9 Tahun 2001 tentang larangan mengomsumsi minuman keras di
Kabupaten Maros. Banyak terjadi pelanggaran terhadap peraturan ini bahkan terlalu sering di jumpai di kalangan remaja namun terkesan dibiarkan berlangsung tanpa ada penindakan dan penertiban.

Mangkunegara (2005) menyatakan bahwa "kinerja merupakan istilah yang berasal dari kata Job Perfomance atau Actual Perfomance (prestasi kinerja atau prestasi sesungguhnya yang dicapai seseorang)."

Umar (2004:76) dalam Dwi Jatmiko mengatakan bahwa pengertian kinerja sebagai berikut : "Kinerja adalah keseluruhan kemampuan seseorang untuk bekerja sedemikian rupa sehingga mencapai tujuan kerja secara optimal dan berbagai sasaran yang telah diciptakan dengan pengorbanan rasio kecil dibandingkan yang secara dengan hasil yang dicapai".

Rivai (2010:548) dalam Wahyudi (2014: 28) mengungkapkan bahwa kinerja karyawan tersebut merupakan hal yang sangat penting dalam upaya perusahaan untuk 
mencapai tujuannya. Adapun salah satu cara yang dapat digunakan untuk melihat perkembangan perusahaan adalah dengan cara melihat hasil penilaian kinerja. Dari hasil penilaian tersebut dapat dilihat kinerja karyawan atau dengan kata lain bahwa kinerja adalah hasil kerja konkret yang dapat diamati dan diukur.

Wibowo (2016: 3) kinerja merupakan implementasi dari rencana yang telah disusun tersebut. Implementasi kinerja dilakukan oleh sumberdaya manusia yang meiliki kemampuan, kompetensi, motivasi, dan kepentingan. Bagaimana organisasi menghargai dan memperlakukan sumber daya manusianya akan memengaruhi sikap dan perilakaunya dalam menjalankan kineranya. Anwar Prabu Mangkunegara (2009: 75) mengemukakan bahwa indikator kinerja, yaitu: Kualitas kinerja adalah seberapa baik seorang karyawan mengerjakan apa yang seharusnya dikerjakan.

Kuantitas kinerja adalah seberapa lama seorang pegawai bekerja dalam satu harinya kuantitas kinerja ini dapat dilihat dari kecepatam kerja setiap pegawai itu masingmasing.

Tanggung jawab terhadap pekerjaan adalah kesadaran akan kewajiban karyawan untuk melaksanakan pekerjaaan yang diberikan perusahaan.

Mangkuprawira dan Vitalaya (2007), menyatakan bahwa, "Penilaian kinerja yang dilakukan dalam sutu organisasi haruslah mengikuti standar kinerja yang ditetapkan, dimana pengukuran kinerja tersebut memberikan umpan balik yang positif kepada pegawai".

Terdapat tiga faktor utama yang berpengaruh pada kinerja, yaitu individu (kemampuan kerja), usaha kerja (keinginan untuk bekerja), dan dukungan organisasional (kesempatan untuk bekerja). Terdapat empat unsur dalam kinerja, yaitu hasil-hasil fungsi pekerjaan, faktor-faktor yang berpengaruh terhadap prestasi karyawan, pencapaian tujuan organisasi, dan periode waktu tertentu (Tika, 2006:121). Penelitian 
menunjukkan bahwa terdapat enam faktor yang secara positif memengaruhi kinerja pada tujuan: supervisory authority (kewenangan pengawasa), peer and group pressure (tekanan rekan dan kelompok), public display (tampilan publik) expectatio of succes (haparan keberhasilan), incentive and reward (insentif dan penghargaan), dan participation (partisipasi), Wibowo (2016: 52). Namun kinerja memerlukan dukungan sarana, kompetensi, peluang, standar, dan uman balik. Kaitan diantara

ketujuh indikator tersebut digambarkan oleh Hersey, Blanchard, dan Johnson dalam Wibowo (2016: 86).

Terdapat kurang lebih dua syarat utama yang diperlukan guna melakukan penilaian kinerja yang efektif, yaitu (1) adanya kriteria kinerja yang dapat diukur secara objektif; dan (2) adanya objektivitas dalam proses evaluasi (Gomes, 2003:136).

Sedangkan dari sudut pandang kegunaan kinerja itu sendiri, Sondang Siagian (2008-223-224) menjelaskan bahwa bagi individu penilaian kinerja berperan sebagai umpan balik tentang berbagai hal seperti kemampuan, keletihan, kekurangan dan potensinya yang pada gilirannya bermanfaat untuk menentukan tujuan, jalur, rencana dan pengembangan karirnya. Sedangkan bagi organisasi, hasil penilaian kinerja sangat penting dalam kaitannya dengan pengambilan keputusan tentang berbagai hal seperti identifikasi kebutuhan program pendidikan dan pelatihan, rekrutmen, seleksi, program pengenalan, penempatan, promosi, sistem balas jasa, serta berbagai aspek lain dalam proses manajemen sumber daya manusia.

Ndraha (2005), mengatakan Pamong Praja adalah mereka yang mengelola kebhinekaan dan mengukuhkan ketunggalikaan. Pamong praja kembali menjadi perbincangan di tengah masyarakat, bahkan petinggi negeri, pengamat pemerintah termasuk penggiat Lembaga Swadaya Masyarakat (LSM) mencurahkan perhatian dan pikirannya untuk beberapa sar setelah kejadian 
"Kota Berdarah" bentrok antara Polisi Pamong Praja dengan warga di makam Mbah Priuk Jakarta tanggal 14 April 2010 dan penertiban Peraturan Mentri Dalam Negara Nomor 26 Thaun 2010 tentang penggunaan senjata bagi Satuan Polisi Pamong Praja.

\section{Satuan Polisi Pamong Praja}

(Satpol PP) mempunyai tugas membantu kepala daerah untuk menciptakan suatu kondisi daerah yang tenteram, tertib, dan teratur sehingga penyelenggaraan roda pemerintahan dapat berjalan dengan lancar dan masyarakat dapat melakukan kegiatannya dengan aman. Oleh karena itu, di samping menegakkan kebijakan, Satuan Polisi Pamong Praja juga dituntut untuk menegakkan kebijakan pemerintah daerah lainnya yaitu peraturan kepala daerah.

Dasar hukum tentang tugas dan tanggung jawab Satuan Polisi Pamong Prajaadalah Peraturan Pemerintah Nomor 6 Tahun 2010 tentang Satuan Polisi Pamoing Praja yang ditetapkan pada tanggal 6 Januari 2010. Dengan berlakunya Peraturan Pemerintah ini maka dinyatakan tidak berlaku Peraturan Pemerintah Nomor 32 Tahun 2004 tentang Pedoman Satuan Polisi Pamong Praja

\section{METODE PENELITIAN}

Penelitian ini akan berlangsung selama dua bulan . Lokasi penelitian penulis adalah di kantor Satuan Polisi Pamong Praja yang berlokasi di Kecamatan Turikale kabupaten Maros dikarenakan di Daerah tersebut termasuk salah satu tempat yang banyak mengomsumsi miras sehingga peran satuan polisi pamong praja dalam melaksanakan perarturan Daerah Nomor 9 Tahun 2001 di Kabupaten Maros.

Penelitian ini menggunakan metode penelitian kualitatif yang berusaha menjelaskan sedetil mungkin objek dan masalah penelitian berdasarkan fakta yang diperoleh dilapangan .

Tipe Penelitian yang digunakan penulis adalah Fenomenologi yakni suatu bentuk penelitian yang bertujuan untuk memberikan gambaran umum berbagai macam data yang dikumpul dari lapangan secara objektif 
bedasarkan fenomena-fenomena yang terjadi bedasarkan pengalaman hidup seseorang.

Bedasarkan sumbernya, data dibedakan menjadi dua, yaitu data primer yaitu Data dikumpulkan sendiri oleh peneliti lansung dari sumber pertama atau tempat objek penelitian dilakukan Melalui wawancara. dan data sekunder yaitu data yang diperoleh untuk mendukung data primer yang sumbernya dari data-data yang sudah diperoleh sebelumnya menjadi seperangkat informasi dalam bentuk dokumen, laporan-laporan, dan informasi tertulis lainnya yang berkaitan dengan peneliti.

Informan dalam penelitian ini adalah Kepala Bidang Penegakan Perundang-Undangan Kantor Satuan Polisi Pamong Praja, Satuan Polisi Pamong Praja di Kabupaten Maros, Masyarakat Kecamatan Turikale di Kabupaten Maros.

Metode atau cara pengumpulan data yang penyusun gunakan dalam penelitian ini adalah dengan cara dokumentasi, observasi, dan wawancara.
Teknik analisis data yang digunakan dalam penelitian ini adalah model analisa interaktif (interactive model of analysis). Dalam model ini terdapat 3 komponen pokok. Menurut Miles dan Huberman dalam Sugiyono (2012) ketiga komponen tersebut yaitu: Reduksi Data, Sajian Data, dan Penarikan Kesimpulan

Keabsahan Data yang digunakan dalam penelitian ini adalah triangulasi yang terdiri dari Triangulasi sumber, Triangulasi teknik, dan Triangulasi waktu.

\section{HASIL PENELITIAN}

Kualitas kerja yang mengacu pada kualitas sumber daya manusia seperti pengetahuan, keterampilan, dan kemampuan yang dimiliki seorang karyawan serta seberapa baik seorang karyawan mengerjakan apa yang seharusnya dikerjakan.

Kemampuan dan keterampilan dalam menangani atau menyikapi suatu masalah merupakan satu poin penting dalam menilai seberapa besar dan meningkatnya kulitas seorang pegawai. 
Minuman keras beralkohol merupakan suatu produk konsumsi yang memiliki pengaruh buruk. Masalah yang ditimbulkan oleh minuman keras beralkohol ini baik dalam kadar alkohol tinggi maupun rendah tetap memberi pengaruh buruk dan menyebabkan berbagai masalah yang kebanyakan adalah sebuah kekacauan atau perkelahian.

Jelas bahwa aturan tentang penggunaan minuman keras menunjuk pihak kepolisian dan polisi pamong praja yang berperan sebagai pengayom masyarakat dan menentramkam lingkungan sekitar serta bertindak mengawasi dari kemungkinan terburuk termasuk penggunaan minuman keras dan lain hal sebagainya.

Minuman keras yang tidak memiliki izin pada hotel,wisma, cafe, dan restoran akan disita dan pada surat keputusan Bupati Maros nomor 49 pasal 3 dikatakan bahwa pihak polisi pamong praja bertindak sebagai pengawas lapangan.

Segala sesuatu harus memilki izin atau keterangan yang jelas termasuk makanan dan minuman.
Tergolong minuman keras adalah hal yang sudah jelas memilki cap haram dalam pandangan masyrakat pada umumnya. Bersangkutan dengan itu tidak sembarangan minuman keras diperjual belikan secara sembarangan di toko atau tempat-tempat lainnya kecuali telah memiliki izin yang jelas.

Kinerja satuan polisi pamong praja kota Maros dalam keadaan mampu menjalankan tugas dan tanggung jawabnya dalam bekerja.

Pengawasan dan penertiban penggunaan minuman keras yang sudah dilakukan terutama pada waktu datangnya bulan suci Ramadhan hingga hari raya Idul Adha mampu memberikan kesan yang baik buat masyarakat khususnya Kota Maros.

Setiap tindakan yang di lakukan oleh Satuan Polisi Pamong Praja dalam mengatasi masalah minuman keras itu harus sesuai dengan perintah atasan yang bersangkutan.

Pekerjaan yang di naungi oleh pemerintahan termasuk Polisi Pamong Praja bukanla satu-satunya dinas yang bekerja sesuai dengan aturan atau perintah dari atasan. Baik itu di pihak 
swasta maupun negeri semua tugas yang dilaksanakan sesuai dengan arahan dari komando.

Satuan Polisi Pamong Praja turun langsung memberikan penjelasan tentang adanya aturan yang mengatur tentang penyelahgunaan minuman beralkohol.

Kinerja Polisi Pamong Praja dalam hal pemahaman mereka bersosialisasi dan memberikan pemahaman kepada instansi dan masyarakat dalam peraturan tentang minuman keras terutama di kalangan anak sekolah.

Memberikan sebuah pemahaman bukan lah hal yang muda apa lagi berharap seseorang dapat mematuhu aturan sesuai dengan arahan. Menyampaikan kepada masyarakat adalah persoalan yang mudah tapi memberikan pemahaman adalah hal lain karena pandangan dan persepsi setiap orang berbeda terutama dalam upaya merubah gaya hidup.

Pemahaman yang diberikan mengenai peraturan minuman keras oleh pihak anggota Satuan Polisi Pamong Praja itu sangat mendukung dalam hal memperbaiki perilaku masyarakat terutama remaja di Kota Maros.

Satuan Polisi Pamong Praja memberi pemahaman masyarakat memegang peran penting dalam segala peraturan yang berlaku agar keadaan lingkungan lebih baik dan mudah dikontrol.

Berhasil tidaknya sebuah aturan itu sangat didukung dengan kerjasama yang baik oleh masyarakat apalagi bersangkutan dengan perilaku seperti minuman keras dan sangat membutuhkan sebuah kesadaran masyarakat.

Kuantitas hasil kerja pegawai mengacu pada kerja pegawai dalam penggunaan waktu tertentu dan kecepatan dalam menyelesaikan tugas dan tanggung jawabnya baik itu dalam pertahunnya, termasuk tanggung jawabnya dalam bekerja dengan tindakan yang sesuai dengan apa yang menjadi aturan dalam bekerja.

Kemampuan kecepatan dalam mengambil tindakan dengan pelanggaran tertentu yang masingmasing anggota dengan masyarakat 
terkait. Waktu yang yan digunakan dalam bekerja harus sesuai dengan aturan yang ada serta tidak mengambil gerakan lain atau gerakan tambahan.

Pihak yang terkait dengan pelanggaran maka diberikan surat teguran sampai tiga kali akan tetapi jika tidak diinahkan maka Satuan

Polisi Pamong Praja memiliki wewenang untuk mengeksekusi tempat tersebut sesuai dengan pelanggaran.

Satuan Polisi Pamong Praja tidak akan mengambil sebuah tindakan langsung tanpa adanya arahan atau surat perintah yang jelas dari atasan.

Instansi terkait diberi surat teguran namun tidak peduli maka baran-barang yang bersangkutan yang masih tersisa akan disita oleh pihak Satuan Polisi Pamong Praja.

\section{Satuan Polisi Pamong Praja} tidak semata-mata melakuan penyitaan tapi juga melakukan pengawasan setelahnya agar dapat memantau tempat tersebut.

Pihak Satuan Polisi Pamong Praja turun tangan tanpa surat perintah untuk mengatasi keributan agar tidak

terlambat untuk mencegah akibat yang lebih parah akan tetapi wajib lapor.

Satuan Polisi Pamong Praja bertindak tanpa surat perintah dan itu merupakan kecepatan dalam bertindak dengan inisiatif, akan tetapi tak di izinkan bertndak perseorangan.

Masalah minuman keras merupakan masalah yang tidak dapat dikategorikan masalah kecil dikarenakan karena jumlah pengguna yang tidak dapat dihitung dan sulit ditetapkan.

Tidak efektivnya sebuah aturan karena masyarakat yang kurang dapat di ajak bekerjasama akan tetapi kinerja Satuan Polisi Pamong Praja sudah cukup baik.

Dalam pelaksanaan tugas
seorang pegawai harus mampu
menjalankan secara efektif dan efesien
ketika suatu tujuan tertentu akhirnya
bisa dicapai tanpa adanya kesalahn
dalam pelaksanaan tugas tersebut.
Pelaksanaan tugas harus terus
ditingkatkan kemampuan dan berusaha
mencari solusi atau cara dalam
menyelesaikan masalah yang kerap
timbul dan tidak memiliki titik terang

Dalam pelaksanaan tugas 
termasuk masalah mimunam keras yang sudah menjamur dimana-mana meski selama dalam pelakasanaan tugas tidak pernah ada masalah karena apa yang lakukan sudah sesuai dengan proses.

Pelaksanaan tugas harus selalu sesuai dengan perencanaan aturan dan selalu ada komunikasi dengan SKPD terkait agar tidak terjadi masalah yang tidak di inginkan baik itu secara pribadi maupun kelompok.

Masalah timbul kapan saja bahkan tidak kenal waktu maka dari itu selaku aparat Satuan Polisi Pamong Praja yang memang sudah memiliki kewajiban menjaga keamanan masyarakat maka harus siap kapan pun dan tidak boleh mudah lengah dalam menjalankan tugas akan tetapi melaksanakan tugas juga tidak boleh sembarangan karena segala sesuatunya memiliki aturan.

Selama ini para anggota yang betugas melaksanakan tugas yang memang sudah di berikan oleh atasan mereka maka para anggota akan melakukan sesuai dengan apa yang telah di arahkan tanpa mengambil keputusan sendiri karena jika demikian banyak resiko yang akan terjadi sehingga terwujudnya apa yang di inginkan dicapai tanpa masalah yang berkelanjutan di belakangnya

Organisasi kemanusiaan memiliki tanggung jawab yang etis terhadap satu sama lain dalam menempuh tugas-tugasnya secara bertanggungjawab dengan integritas dan cara yang relevan serta tepat.

Organisasi kemanusiaan harus meyakinkan bahwa mereka hanya akan berkomitmen terhadap suatu kegiatan ketika mereka memiliki alat, kompetensi, keahlian, dan kapasitas untuk mewujudkan komitmen tersebut.

Penertiban minuman keras di Maros ini sangat susah karena produsen dan konsumennya yang sulit dikontrol.

Satuan Polisi Pamong Praja selaku instans yang telah diberi tanggungjawab akan pengawasan masalah minuman keras akan tetap bekerja keras dalam menangani masalah tersebut.

Satuan Polisi Pamong Praja bertangung jawab pada tugas yang 
diberikan oleh pemerintah terkait Peraturan Daerah tentang larangan mengomsumsi minuman keras.

Anggota Satuan Polisi Pamong Praja selalu siap turun langsung ke lapangan apabila mendapati perintah dari atasan karena sudah menjadi tangung jawabnya. Satuan Polisi Pamong Praja adalah pengawal

peraturan daerah dan mutlak menjalankan peraturan daerah tersebut.

Disiplin dalam bekerja satuan organisasi yang baik selalu mempunyai aturan internal dalam rangka meningkatkan kinerja dan profesionalisme, budaya organisasi maupun kebersamaan, kehormatan, dan kredebilitas organisasi serta untuk menjamin tetap terpeliharanya tata tertib dalam pelaksanaan tugas sesuai tujuan, peran, fungsi, wewenang, dan tanggung jawab institusi tersebut.

Anggota Satuan Polisi Pamong

Praja selama betugas para anggota disiplin dalam melaksanakan tugas karena sudah menjadi tanggung jawab dari pemerintah kota Maros. Polisi Pamong Praja selalu dihimbau agar disiplin dan teratur dalam melaksanakan tugas.

\section{Anggota Satuan Polisi Pamong} Praja disiplin sudah melekat dan harus dilakukan dalam kehidupan sehari-hari baik itu sebagai pengawal pemerintah atau pun masyarakat biasa.

\section{Anggota Satuan Polisi Pamong} Praja yang berada dibawah naungan pemerintah maka wajib menjalankan apa yang telah dikatakan atasan telah terkait masalah pekerjaan dan tanggung jawab sudah seharusnya disiplin dalam melaksanakan tugas.

Kemampuan yaitu kecakapan yang dimiliki oleh seseorang yang baik dari pengetahuan yang didapat melalui pendidikan formal atau keterampilan yang dimilikinya. Dengan kemampuannya ini maka akan dapat meningkatkan produktivitas kerja.

Apabila terjadi kekacauan yang berhubungan dengan minuman keras maka para anggota Satuan Polisi Pamong Praja tidak akan segan-segan menindaklanjuti para pelaku.

Para pelaku minuman keras yang di tangkap dibawa ke kantor untuk diminta klarifikasi dan semua 
barang-barang yang berkenaan dengan kejadian akan di amankan. Berkenaan dengan hal tersebut tidak sedikit pula aksi kejar-kejaran yang dilakukan apabila para pelaku yang ditemukan terutama pengomsumsi yang lari atau bersembunyi. Diantara semua kasus minuman keras yang paling membuat para aparat merasa jengkel adalah adanya permainan judi yang berujung pada perkelahian dan tidak lain para tersangka dibawah pengaruh alkohol bahkan obat-obatan.

Anggota Satuan Polisi Pamong Praja berusaha melatih dan mengasah kemampuan mereka dalam menjalankan tugas sebaik mungkin. Manusia akan mampu melaksanakan kegiatannya dengan baik, sehingga dicapai suatu hasil yang optimal, apabila ditunjang oleh suatu kondisi lingkungan yang sesuai.

Pembuat minuman keras yang sudah menjamur sehingga para pengguna juga tak bisa berhenti dan untuk memberhentikannya tidak bisa di lakukan begitu saja jadi yang paling dibutuhkan adalah kerjasama masyrakat.
Keberhasilan sebuah Peraturan Daerah berasal dari kerjasama yang baik dan kesadaran dari masyarakat terutama dalam remaja.

Masyarakat adalah sumber harapan terbesar dalam terealisasinya sebuah aturan terutama menyangkutan mengomsumsi maupun memproduksi minuman keras. Selama masyarakat yang sudah terbiasa atau bahkan menjadikannya kebiasaan maka perlu merubah gaya hidupnya sedangkan yang memproduksi diperlukan merubah cara pandang dalam memenuhi perekonomian.

Minuman keras sudah memasuki kehidupan para remaja yang sedang dalam masa pertumbuhan dan yang paling berperan penting disini adalah keluarga dalam hal mengawasi, memperhatikan, dan bertanggung jawab terhadap perilaku anak ataupun orang terdekatnya.

Remaja bahkan yang dapat dikatan anak-anak dibawah umur telah yang belum semestinya mengomsumsi minuman keras justru menjadi sebuah kebiasaan. Minuman beralkohol memiliki dampak negatif yang begitu 
besar apalagi ketika para remaja mulai mencampurnya dengan meminum obat-obat yang terlarang. Sungguh kekhawatiran yang luar biasa ketika kasus demikian sudah beberapakali didapat yakni anak SMP dan anak SMA.

Mengomsumsi minuman keras, merokok, dan menggunakan obat terlarang dengan alasan yang hampir sama yakni penghilang stress dan peningkatan kepercayaan diri. Kekacauan seperti ini sudah dapat dikategorikan perilaku dan sikap yang bobrok. Jika ditinjau lebih dalam kesalahan fatal ini adalah kurangnya perhatian dari keluarga.

Efektifnya sebuah peraaturan daerah terutama peraturan daerah nomor 9 tahun 2001 mengenai larangan mengomsumsi minuman keras yaitu adanya kerjasama yang baik dari pihak masyarakat.

\section{KESIMPULAN}

Berdasarkan hasil penelitian dan dilakukannya analisis pembahasan yang telah dikemukakan, maka selanjutnya dikemukakan kesimpulan sebagai berikut:
Kinerja pegawai Satuan Polisi Pamong Praja jika dilihat dari aspek pelaksanaan tugas di lapangan menunjukkan bahwa kurang efektif. Hal tersebut dapat dilihat bahwa kinerja Satuan Polisi Pamong Praja belum mampu menjalanka tugas dan fungsinya dalam menertibkan penggunaan minuman keras yang suda menjamur hingga menyentuh pergaulan remaja di berbagai titik.

$$
\text { Kinerja Satuan Polisi Pamong }
$$

Praja Kabupaten Maros dalam upaya melakukan penertiban penggunaan minuman keras dari aspek tanggung jawab masih belum optimal. Hal tersebut dapat dilihat bahwa tingkat konsistensi kebijakan dan kegiatan penertiban penggunaan minuman keras belum sesuai dengan tugas dan fungsinya.

Banyaknya rencana kerja yang tidak berjalan sesuai dengan yang diharapkan memiliki alasan tersendiri. Berjalan dengan baik tidaknya sebuah kebijakan tergantung bagaimana kinerja pegawai yang menjalankan tapi berbagai faktor dapat menjadi penghambat, diantara faktor-faktor 
penghambat yaitu disiplin, kemampuan, dan lingkungan yang paling mempengaruhi kinerja pegawai dalam menjalankan tugas dengan baik yakni faktor lingkungan.

\section{DAFTAR PUSTAKA}

Dharma, Agus. 2003. Manajemen Supervisi: Petunjuk Praktis Bagi Para Supervisor. Jakarta: Raja Grafindo Persada.

Gomes, Faustino Cardoso. 2003.

Manajemen Sumber Daya Manusia. Edisi kedua. Penerbit Andi Offset, Yogyakarta.

Mangkunegara, Anwar Prabu., 2005. Evaluasi Kinerja SDM, Bandung: PT Refika Aditama.

Mangkuprawira, Sjafri dan Aida Vitayala Hubies. 2007. Manajemen Mutu Suber Daya Manusia. Bogor: Ghalia Indonesia.

Sondang P. Siagian (2008). Manajemen Sumber Daya Manusia. Jakarta : Bumi Aksara.
Organisasi, Gramedia Pustaka, Jakarta.

Veitzhal, Rivai, 2004. Manajemen Sumber Daya Manusia Untuk Perusahaan, Cetakan Pertama,Jakarta, PT.Raja Grafindo Persada.

Wahyudi., 2014. Pengaruh Pemberian Insentif terhadap Kinerja Pegawai Lingkup Badan Pemberdayaan Masyarakat Pemerintahan Desa dan Kelurahan Provinsi Sulawesi Selatan, Makassar pada 22 Agustus 2014.

Wibowo., 2016. Edisi Kelima Manajemen Kinerja. PT.Raja Grafindo Persada: Jakarta.

Tika, Pabundu 2006, Budaya Organisasi dan Peningkatan Kinerja Perusahaan, Jakarta: Cetakan Pertama, PT Bumi Aksara.

Umar, Husein. (2004). Riset Sumber Daya Manusia dalam 